\title{
An In Vitro Model for Cytogenetic Conversion in CML Interferon- $\alpha$ Preferentially Inhibits the Outgrowth of Malignant Stem Cells Preserved in Long-Term Culture
}

\author{
Jan J. Cornelissen, ${ }^{\star}$ Rob E. Ploemacher, ${ }^{\ddagger}$ Bert W. Wognum, ${ }^{\ddagger}$ Astrid Borsboom, ${ }^{\ddagger}$ Hanneke C. Kluin-Nelemans, ${ }^{\S}$ \\ Anne Hagemeijer, $\|$ and Bob Löwenberg ${ }^{\star \neq}$ \\ *Department of Hematology, Daniel den Hoed Cancer Center, Rotterdam, 3075 EA, The Netherlands; ${ }^{\ddagger}$ Institute of Hematology, Erasmus \\ University Rotterdam, Rotterdam, 3015 GE, The Netherlands; ${ }^{\S}$ Department of Hematology, Leiden University Medical Center, Leiden, \\ 2333 ZA, The Netherlands; and ${ }^{\|}$Center for Human Genetics, University of Leuven, Leuven, 3000, Belgium
}

\begin{abstract}
IFN- $\alpha$ has been shown to prolong survival in chronic myeloid leukemia patients, but its mechanism of action is still not understood. The human cobblestone area-forming cell (CAFC) assay allows for the measurement of the concentration of normal as well as malignant stem cells, while their progeny can be measured in parallel long-term culture (LTC) in flasks. Using CAFC and LTC assays, we have examined direct effects of IFN- $\alpha(500 ; 5,000 \mathrm{IU} / \mathrm{ml})$ on the maintenance and outgrowth of CD34-enriched normal and malignant stem cells, obtained from six patients with an established major cytogenetic response to IFN- $\alpha$ and from four nonresponding patients. CAFC concentrations were not affected by IFN- $\alpha$. In contrast, IFN- $\alpha$ strongly inhibited the clonogenic output in flask LTC. Nucleated cells (NC) produced in LTC were evaluated by fluorescent in situ hybridization (FISH) for the presence of the Philadelphia (Ph) translocation. After $8 \mathrm{wk}$ of LTC, the percentage of $\mathbf{P h}^{+}$ NCs produced was significantly more inhibited by IFN- $\alpha$ in responding patients than in nonresponders. Control LTC without IFN- $\alpha$ showed no significant differences of $\mathrm{Ph}^{+} \mathrm{NC}$ production between responders and nonresponders. These findings provide the first in vitro model for cytogenetic conversion and suggest that direct antiproliferative effects of IFN- $\alpha$ account for the cytogenetic response observed clinically. (J. Clin. Invest. 1998. 102:976-983.) Key words: interferon- $\alpha \cdot$ long-term culture - cobblestone area-forming cell assay • chronic myeloid leukemia $\bullet$ cytogenetic response
\end{abstract}

\section{Introduction}

Chronic myeloid leukemia (CML) $)^{1}$ is a malignant clonal disorder of hematopoietic stem cells (1). The neoplastic cells are

Part of this work was presented at the 38th annual meeting of the American Society of Hematology (1996. Blood. 88:637a).

Address correspondence to Jan J. Cornelissen, M.D., Ph.D., Daniel den Hoed Cancer Center, Department of Hematology, Groene Hilledijk 301, 3075 EA Rotterdam, The Netherlands. Phone: 31-10-4391367; FAX: 31-10-4842008; E-mail: Cornelissen@hemh. azr.nl

Received for publication 26 November 1997 and accepted in revised form 14 July 1998.

J. Clin. Invest.

(C) The American Society for Clinical Investigation, Inc. 0021-9738/98/09/0976/08 \$2.00

Volume 102, Number 5, September 1998, 976-983

http://www.jci.org characterized by a unique gene rearrangement as a result of a reciprocal translocation between the long arm of chromosome 9 and chromosome 22, known as Philadelphia chromosome $(\mathrm{Ph})(2)$. The gene rearrangement results in the creation of a $b c r / a b l$ fusion gene, which encodes for a chimeric protein (p210) with tyrosine kinase activity (3). Characteristically, CML has a biphasic course, evolving from chronic phase (CP) with a median duration of 3-4 yr to an accelerated phase and blast crisis, which is usually fatal within 3-6 mo. Preferably, patients are treated in $\mathrm{CP}$ in order to postpone or offset blastic transformation.

Allogeneic bone marrow (BM) transplantation is the only curative treatment available, but is only applicable in a minority of patients (15-20\%) for whom an HLA identical (sibling) donor can be found and who are under the age of 50-55 $\mathrm{yr}$ (4). Alternative treatment strategies for patients, who do not have the option of allogeneic BM transplantation, include IFN- $\alpha$ alone or in combination with chemotherapeutic agents such as hydroxyurea and cytarabine. Treatment with IFN- $\alpha$ may prolong the overall median survival. Several randomized as well as nonrandomized studies have shown that survival of patients treated with IFN- $\alpha$ may be significantly longer than that of patients receiving hydroxyurea or busulfan (5-9). However, the beneficial effect of IFN- $\alpha$ appears to be restricted to a subgroup of patients (10-15\%) who achieve a partial or complete cytogenetic response after IFN- $\alpha$ treatment. The actuarial survival at $5 \mathrm{yr}$ for these patients is $\sim 90 \%$, while survival for patients without a cytogenetic response is in the order of $45-50 \%$ at $5 \mathrm{yr}$, which is probably not different from that observed after hydroxyurea alone.

Several investigators have addressed the question as to how IFN- $\alpha$ may exert its beneficial effects. It has been suggested that IFN- $\alpha$ may restore defective adhesion of CML progenitors to BM stroma, thereby allowing normal growth inhibitory signals to restore physiological regulation of stem cell growth (10-12). Alternative explanations include a direct antiproliferative effect of IFN- $\alpha$ on CML progenitors or immunological control of malignant cell growth (13-16). However, the precise biological basis of the therapeutic effect of IFN- $\alpha$, which is predominantly observed in patients with a cytogenetic response, is still not resolved. It is not known by which biological mechanism most CML patients are resistant to IFN- $\alpha$.

1. Abbreviations used in this paper: $\mathrm{BFU}-\mathrm{E}$, burst-forming units erythroid; $\mathrm{BM}$, bone marrow; $\mathrm{CA}$, cobblestone area; CAFC, cobblestone area-forming cells; CFU-GM, colony-forming units granulocyte macrophage; CML, chronic myeloid leukemia; $\mathrm{CP}$, chronic phase; FISH, fluorescent in situ hybridization; G-CSF, granulocyte colony-stimulating factor; IC, initiating cells; LTC, long-term culture; NC, nucleated cells; PB, peripheral blood; Ph, Philadelphia. 
Long-term cultures (LTCs) of normal and malignant hematopoietic cells have been used to study the relationship between primitive and committed hematopoietic progenitor cells and the marrow microenvironment (17). Such studies may potentially help to clarify the biological basis of the therapeutic effect of IFN- $\alpha$. We have reported previously on the use of the murine FBMD-1 stromal cell line to establish a limiting dilution type long-term stroma-supported culture (LTC) assay that allows frequency analysis of murine $(18,19)$, rhesus monkey (20), and human hematopoietic stem cells (21). In this LTC, stem cells form phase-dark stroma-associated clones of immature hemopoietic cells (cobblestone areas, CA) (22). Early appearing, transient CAs represent spleen colony-forming stem cells (CFU-S day 12), whereas cells giving rise to late appearing CAs are related to primitive stem cells with long-term repopulating ability (23). Furthermore, we have shown recently that the FBMD-1 stromal cell line allows long-term growth of leukemic stem cells $(24,25)$. Both leukemic and normal stem cells obtained from individual CML patients were maintained efficiently throughout LTC (25). Such LTC provides a model to evaluate differential effects of cytokines or drugs on normal and malignant stem cells in CML. In this study we have investigated the inhibitory effects of IFN- $\alpha$ on the maintenance and outgrowth of normal and malignant stem cells obtained from CML patients with a well-documented clinical response to IFN- $\alpha$.

\section{Methods}

Patients. BM samples and peripheral blood (PB) samples used for this study were obtained after informed consent from CML patients in first CP. Response criteria were as follows. Complete hematological responses were: normalization of peripheral white blood cell counts to levels $<10,000 / \mu l$ and normal differentials with no immature forms (blasts, promyelocytes, myelocytes, or metamyelocytes); normalization of platelet counts to $<450,000 / \mu l$; disappearance of all clinical symptoms and signs of disease including palpable splenomegaly. Cytogenetic responses were: absent: $\mathrm{Ph}$ chromosome persists in all analyzable metaphases; minimal: $\mathrm{Ph}$ chromosome in $>35 \%$ of metaphases; partial: Ph chromosome in $<35 \%$ of metaphases; complete: total elimination of $\mathrm{Ph}$ chromosome cells; major: either complete or partial $\left(\geq 65 \% \mathrm{Ph}^{-}\right.$cells $)$.

Enrichment of $\mathrm{CD} 34^{+}$progenitor cells. Cryopreserved samples were thawed at $37^{\circ} \mathrm{C}$ and slowly diluted with Iscove's medium containing $10 \%$ FBS and $3 \mathrm{U} / \mathrm{ml}$ of DNase I. Cells were pelleted and resuspended for antigen staining in PBS containing 1\% FBS (Hyclone, Logan, UT). Fresh samples were diluted 1:1 with Hanks' balanced salt solution (GIBCO BRL, Gaithersburg, MD), and mononuclear cells were obtained by layering the cells over Ficoll (Lymphoprep; Nygaard, Oslo, Norway). A CD $34^{+}$cell preenriched fraction was prepared by immunomagnetic bead selection by the anti-CD34 mAb 561 coated to immunomagnetic latex beads (Dynal, Oslo, Norway), followed by quantitative elution with anti-Fab antiserum (Detachabead). Alternatively, $\mathrm{CD} 34^{+}$cells were purified using avidin-biotin immunoadsorption columns (CellPro Inc., Bothell, WA) as described previously (26).

Immunofluorescence analysis. CD34 staining was performed by incubating $10^{6}$ nucleated cells (NCs) after erythrocyte lysis for $30 \mathrm{~min}$ with anti-CD34-FITC (HPCA-2 mAb; Becton Dickinson, San Jose, CA). Incubations were performed in Hanks' balanced salt solution containing $2 \%(\mathrm{wt} / \mathrm{vol}) \mathrm{FCS}$ and $0.05 \%$ (vol $/ \mathrm{vol})$ sodium azide. After incubation the cells were washed and resuspended in Hanks' balanced salt solution at a concentration of $2 \times 10^{6}$ cells $/ \mathrm{ml}$. Analytical two-color experiments were performed using a FACScan ${ }^{\circledR}$ flow cytometer (Becton Dickinson). Spillover of FITC fluorescence in the
RPE detector was electronically compensated using appropriately stained control cells. List mode data for 10,000-50,000 cells were collected either ungated or in an electronic gate for cells with intermediate-to-high forward light scatter and low-to-intermediate right angle light scatter to exclude dead cells and mature granulocytes from the analysis. Flow cytometric data were analyzed using Lysys II software (Becton Dickinson).

Hematopoietic growth factors. For the in vitro studies the following purified recombinant human growth factors were kindly provided: granulocyte colony-stimulating factor (G-CSF; Amgen, Thousand Oaks, CA), granulocyte-macrophage colony-stimulating factor (GM-CSF; Genetics Institute, Cambridge, MA), and stem cell factor (Immunex, Seattle, WA). Purified recombinant human erythropoietin was purchased from Boehringer Mannheim (Mannheim, Germany). IFN- $\alpha-2 a$ was obtained from Roche (Mijdrecht, The Netherlands).

Stromal feeders. The FBMD-1 stromal cell line was used as described before (18). In brief, stromal feeders were prepared by seeding $10^{5}$ FBMD-1 cells from log-phase cultures into $25-\mathrm{cm}^{2}$ culture flasks (Costar Corp., Cambridge, MA) or $10^{3}$ cells per well into flatbottomed 96-well plates (Falcon, Lincoln Park, NJ). Culture plastics destined for establishment of FBMD-1 stromal feeders were incubated overnight at $4^{\circ} \mathrm{C}$ with $0.2 \%$ gelatin (Sigma Chemical Co., St. Louis, $\mathrm{MO}$ ) in demineralized water to improve adherence of the stromal layer. The FBMD-1 cells were cultured in $\alpha$-modified DME (GIBCO BRL) supplemented with Hepes (3.5 mM; Sigma), glutamine (2 mM; Sigma), sodium-selenite $\left(10^{-7} \mathrm{M}\right), \beta$-mercaptoethanol $\left(10^{-4} \mathrm{M}\right), 10 \%$ FCS, $5 \%$ horse serum (GIBCO BRL), and hydrocortisone 21-hemisuccinate $\left(10^{-5} \mathrm{M}\right.$; Sigma). After $7-10 \mathrm{~d}$ of culture at $33^{\circ} \mathrm{C}$ and $10 \% \mathrm{CO}_{2}$, the stromal layers had reached confluence and were overlaid with CML progenitors within the subsequent 2 wk.

LTCs in flasks. Confluent stromal layers of FBMD-1 cells in 25$\mathrm{cm}^{2}$ flasks were overlaid with $15-30 \times 10^{3} \mathrm{CD} 34^{+}$preenriched NCs. The cells were cultured in $\alpha$-modified DME supplemented with Hepes $(3.5 \mathrm{mM})$, glutamine $(2 \mathrm{mM})$, sodium-selenite $\left(10^{-7} \mathrm{M}\right), \beta$-mercaptoethanol $\left(10^{-4} \mathrm{M}\right), 20 \%$ horse serum, and hydrocortisone 21 hemisuccinate $\left(10^{-6} \mathrm{M}\right)$. IL-3 $(12 \mathrm{ng} / \mathrm{ml})$ and G-CSF $(20 \mathrm{ng} / \mathrm{ml})$ were added weekly to the culture. Flask cultures were set up in duplicate and maintained at $33^{\circ} \mathrm{C}$ and $10 \% \mathrm{CO}_{2}$ for 8 wk with weekly halfmedium changes and removal of half of the nonadherent cells. The number of NC produced as well as the clonogenic cell output of individual flask cultures was determined on weeks $2,4,6$, and 8 . A single cell suspension was taken up in medium and several concentrations of the cell suspension were plated in a clonogenic cell assay.

Clonogenic cell assays. Quantification of the number of colonyforming units granulocyte macrophage (CFU-GM) and burst-forming units erythroid (BFU-E) was performed using a semisolid $(1 \%$ methylcellulose; Methocel, Stade, Germany) culture medium (Iscove's modified Dulbecco's medium; GIBCO BRL) at $37^{\circ} \mathrm{C}$ and $5 \%$ $\mathrm{CO}_{2}$. The cultures contained $10 \%$ FCS, $0.75 \%$ BSA (A9418; Sigma) supplemented with human transferrin $(0.6 \mathrm{mg} / \mathrm{ml}$; Behringwerke, Marburg, Germany), lecithin $(20 \mu \mathrm{g} / \mathrm{ml}$; Merck, Darmstadt, Germany), sodium-selenite $(0.2 \mathrm{ng} / \mathrm{ml}$; Merck $), \beta$-mercaptoethanol $(5 \times$ $10^{-5} \mathrm{M}$; Merck), erythropoietin (1 U/ml), IL-3 (15 ng/ml), G-CSF (50 $\mathrm{ng} / \mathrm{ml}), \mathrm{GM}-\mathrm{CSF}(5 \mathrm{ng} / \mathrm{ml})$, and stem cell factor $(50 \mathrm{ng} / \mathrm{ml})$ all at final concentrations. CFU-GM and BFU-E were counted on day 14 of culture in the same dish. Their added number (CFU-C) is presented as clonogenic output of LTC.

Cobblestone area-forming cell (CAFC) assay. Confluent stromal layers of FBMD-1 cells in flat-bottomed 96-well plates were overlaid with NCs in a limiting dilution setup. Input values ranged between 1 and 3,000 NCs per well for purified CD $34^{+}$cells. 12 dilutions twofold apart were used for each sample with 15 replicate wells per dilution. The cells were cultured in the same medium and under the same conditions as the LTCs in flasks. To diminish the excessive nonadherent cell production and consequently increase the visibility of the CAs, a hydrocortisone 21-hemisuccinate concentration of $10^{-5} \mathrm{M}$ instead of 
$10^{-6} \mathrm{M}$ was used in the CAFC culture medium. The percentage of wells with at least one phase-dark hematopoietic clone of at least five cells (i.e., CA) beneath the stromal layer was determined weekly for 6 wk and CAFC frequencies were calculated using Poisson statistics as described previously (18).

Slide preparation for fluorescent in situ hybridization (FISH). Cells were pelleted in $15 \mathrm{ml}$ screw-capped tubes using a table-top centrifuge and washed once with RPMI containing $10 \mathrm{U} / \mathrm{ml}$ of heparin. After a hypotonic shock with $0.075 \mathrm{M} \mathrm{KCl}$ for $5 \mathrm{~min}$, cells were fixed with methanol/acetic acid (3:1) for $15 \mathrm{~min}$. For slide preparation, cells were applied to clean glass slides. Slides were stored at $-80^{\circ} \mathrm{C}$ until use.

FISH. In double-color FISH, a mixture of $b c r$ and $a b l$ probes was used, that were labeled by standard nick translation using either biotin-16-dUTP or digoxigenin-11-dUTP (both from Boehringer Mannheim). After heat denaturation, $25-50 \mathrm{ng}$ of probe was preannealed with $10 \mu \mathrm{g}$ of Cot-1 DNA for $1-3 \mathrm{~h}$ at $37^{\circ} \mathrm{C}$. The hybridization mixture contained the probes and Cot- 1 DNA in $50 \%$ formamide, $10 \%$ dextran-sulfate in $2 \times$ SSCP. All details concerning pretreatment of slides, hybridization, washing, and immunochemical detection were as reported (27). The probes used were Cos-ABL-18, a 40-kb fragment containing the $3^{\prime}$ coding region of the human abl gene, and Cosbcr-51, containing a $35.5-\mathrm{kb}$ fragment representing most of the first exon and part of the first intron of $b c r$. The slides were analyzed using a fluorescent microscope equipped with a triple band pass filter for simultaneous excitation of FITC, Texas red, and DAPI. All analyses were performed using cells with good nuclear morphology and complete, nonoverlapping nuclei. For each hybridization experiment, at least 100 nuclei were scored (technicians were unaware of the clinical response of the patients). A cell was scored $\mathrm{Ph}^{-}$if two distinct red and two distinct green signals were visible within a nucleus. A cell was scored $\mathrm{Ph}^{+}$if it contained one distinct red signal, one distinct green signal, and one distinct yellow signal representing the coincidence of a red and green signal. In addition, a cell was scored $\mathrm{Ph}^{+}$if it contained two distinct red signals and two distinct green signals with one red signal and one green signal in close juxtaposition. All other cells that contained fewer signals were not scored as $\mathrm{Ph}^{+} \mathrm{Or} \mathrm{Ph}^{-}$, but were used to calculate the hybridization frequency, which ranged from 80 to $90 \%$ for this study, implying that two $a b l$ and two $b c r$ signals were visible in at least $80 \%$ of all cells. Cytospin slides prepared from thawed $\mathrm{CD}_{3}{ }^{+}$selected progenitor cells obtained (after informed consent) from a patient with established accelerated CML were used as positive control slides. Cytogenetic evaluation of these $\mathrm{CD} 34^{+}$progenitor cells yielded $100 \% \mathrm{Ph}^{+}$metaphases (30/30) without additional cytogenetic abnormalities. Evaluation by FISH yielded positivity for bcr $/ a b l$ of $97 \pm 2 \%(n=8)$. Cytospin slides prepared from thawed $\mathrm{CD} 4^{+}$selected progenitor cells obtained (after informed consent) from a patient with breast cancer were used as negative control slides, yielding a positivity for $b c r / a b l$ of $2 \pm 1 \%(n=7)$. Experiments were considered of sufficient quality if the hybridization frequency was $>80 \%$ and positive and negative controls yielded, respectively, a percentage of at least $95 \%$ (positive control) and $<5 \%$ (negative control).

Data analysis. Data were analyzed using SlideWrite Plus for DOS Version 6.0 (Advanced Graphics Software, Carlsbad, CA). Curve fits were performed using a least squares regression fit. Correlation coefficients were calculated using two-tailed $t$ test or Wilcoxon rank-sum (Mann-Whitney) test in case of unequal variances.

\section{Results}

Patients. Patient characteristics are presented in Tables I and II. Six patients developed a major cytogenetic response after IFN- $\alpha$ treatment, including three complete responses and three partial responses. The median time to their best cytogenetic response was $\sim 2$ yr (range $8-54 \mathrm{mo}$ ). All cytogenetic responses were preceded by a complete hematological response, which was achieved at a median time of 3 mo after diagnosis (range 2-6 mo). Four patients failed to show a cytogenetic response after treatment with IFN- $\alpha$ for at least 50 mo (range 59-84 mo). However, two out of these four patients achieved a complete hematological response. BM or PB samples used for our experiments were the earliest samples available, which were obtained within 3 mo of diagnosis for six patients and between 5 and 28 mo from diagnosis for the other four patients.

Effect of IFN- $\alpha$ on CAFC frequency. $\mathrm{CD}^{+} 4^{+}$selected cells were assayed for their concentration of CAFC. Enrichment of CD $34^{+}$cells resulted in a mean purity of $75 \% \mathrm{CD}^{+} 4^{+}$cells (range 49-92\%). Stromal layers were overlaid with CD34 NCs in a limiting dilution setup either in the presence or absence of IFN- $\alpha$. Initially, IFN- $\alpha$ was added to final concentrations of 50 and $500 \mathrm{IU} / \mathrm{ml}$. No inhibitory effect of IFN- $\alpha$ was observed when CAFC frequencies were assayed weekly during a culture period of $9 \mathrm{wk}$. This is exemplified for patient 6 in Fig. 1. As no inhibitory effect was observed, a higher dosage of IFN- $\alpha$ was also evaluated. Therefore, in subsequent experiments, the dosage of IFN- $\alpha$ was increased to a final concentration of 5,000 IU/ml, which was added every week to the cultures. Cumulative results with progenitor cells from three responding and three nonresponding patients are presented in Fig. 2. Cytogenetic responders were patients 1-3 (Table I) and nonresponders were patients 7-9 (Table II). CAFC concentrations are presented as percentages of concentrations assayed by parallel control cultures without IFN- $\alpha$. No significant in-

Table I. Characteristics of IFN- $\alpha$ Responsive Patients

\begin{tabular}{|c|c|c|c|c|c|c|c|c|c|}
\hline \multirow[b]{3}{*}{ Patient } & \multirow[b]{3}{*}{ Age (yr)/sex } & \multirow[b]{3}{*}{$\begin{array}{l}\text { Clinical status } \\
\text { at diagnosis }\end{array}$} & \multicolumn{4}{|c|}{ Response to IFN- $\alpha$} & & & \\
\hline & & & \multicolumn{2}{|c|}{ Hematological } & \multicolumn{2}{|c|}{ Cytogenetic } & \multicolumn{3}{|c|}{ Study sample } \\
\hline & & & Type & $\begin{array}{c}\text { Time from } \\
\text { diagnosis }\end{array}$ & $\begin{array}{c}\% \text { of } \mathrm{Ph}^{+} \\
\text {metaphases }\end{array}$ & $\begin{array}{c}\text { Time from } \\
\text { diagnosis }\end{array}$ & $\begin{array}{c}\% \text { of } \mathrm{Ph}^{+} \\
\text {metaphases }\end{array}$ & $\begin{array}{c}\text { Time from } \\
\text { diagnosis }\end{array}$ & Source \\
\hline & & & & mo & & mo & & mo & \\
\hline 1 & $40 / \mathrm{F}$ & $\mathrm{CP}$ & $\mathrm{CHR}$ & 6 & 3 & 25 & 100 & 5 & $\mathrm{BM}$ \\
\hline 2 & $28 / \mathrm{F}$ & $\mathrm{CP}$ & CHR & 3 & 0 & 54 & 100 & 0 & $\mathrm{BM}$ \\
\hline 3 & $52 / \mathrm{M}$ & $\mathrm{CP}$ & CHR & 2 & 0 & 47 & 100 & 0 & $\mathrm{BM}$ \\
\hline 4 & $56 / \mathrm{F}$ & $\mathrm{CP}$ & CHR & 2 & 0 & 14 & 100 & 0 & PB \\
\hline 5 & $24 / F$ & $\mathrm{CP}$ & CHR & 3 & 25 & 29 & 81 & 18 & $\mathrm{BM}$ \\
\hline 6 & $56 / \mathrm{M}$ & $\mathrm{CP}$ & $\mathrm{CHR}$ & 2 & 35 & 8 & 100 & 0 & $\mathrm{~PB}$ \\
\hline
\end{tabular}




\begin{tabular}{|c|c|c|c|c|c|c|c|c|c|}
\hline \multirow[b]{3}{*}{ Patient } & \multirow[b]{3}{*}{ Age $(y r) / s e x$} & \multirow[b]{3}{*}{$\begin{array}{l}\text { Clinical status } \\
\text { at diagnosis }\end{array}$} & \multicolumn{4}{|c|}{ Response to IFN- $\alpha$} & & & \\
\hline & & & \multicolumn{2}{|c|}{ Hematological } & \multicolumn{2}{|c|}{ Cytogenetic } & \multicolumn{3}{|c|}{ Study sample } \\
\hline & & & Type & $\begin{array}{c}\text { Time from } \\
\text { diagnosis }\end{array}$ & $\begin{array}{c}\% \text { of } \mathrm{Ph}^{+} \\
\text {metaphases }\end{array}$ & $\begin{array}{l}\text { Time from } \\
\text { diagnosis }\end{array}$ & $\begin{array}{c}\% \text { of } \mathrm{Ph}^{+} \\
\text {metaphases }\end{array}$ & $\begin{array}{c}\text { Time from } \\
\text { diagnosis }\end{array}$ & Source \\
\hline & & & & mo & & mo & & mo & \\
\hline 7 & $62 / \mathrm{M}$ & $\mathrm{CP}$ & CHR & 3 & 100 & $<59$ & 100 & 0 & $\mathrm{BM}$ \\
\hline 8 & $48 / \mathrm{M}$ & $\mathrm{CP}$ & Partial & & 100 & $<63$ & 100 & 0 & $\mathrm{BM}$ \\
\hline 9 & $59 / \mathrm{M}$ & $\mathrm{CP}$ & Partial & & 100 & $<60$ & 100 & 6 & BM \\
\hline 10 & $29 / \mathrm{M}$ & $\mathrm{CP}$ & CHR & 6 & 100 & $<84$ & 100 & 28 & BM \\
\hline
\end{tabular}

hibitory effect was observed after 8 wk of culture. Neither the number nor the size of CA (results not shown) was affected by IFN- $\alpha$ in responding as well as nonresponding patients.

Effects of IFN- $\alpha$ on production of NCs and committed progenitors. $\mathrm{CD}_{3}{ }^{+}$selected progenitor cells were also cultured in flask LTC. Stromal layers of FBMD-1 cells were overlaid with $\mathrm{CD} 34^{+}$progenitor cells and the number of NCs produced was determined every other week. In addition, NCs produced were assayed for CFU-GM and BFU-E recovery after plating in secondary clonogenic cell cultures. The cumulative production of CFU-GM and BFU-E after 8 wk of culture was calculated. Results are shown in Figs. 3 and 4. Weekly addition of IFN- $\alpha$ to flask LTC resulted in a significant and dose-dependent inhibition of the production of $\mathrm{NC}$ and the production of CFU-GM and BFU. Production was inhibited in all patients, including cytogenetically responding as well as nonresponding patients. After 8 wk of flask LTC, nonadherent cells were removed and assayed as described. Subsequently, adherent cells were also removed and assayed for CFU-GM and BFU-E recovery after plating in secondary clonogenic cultures. Results are presented in Fig. 5. Adherent cells from flask LTC without weekly addition of IFN- $\alpha$ produced significantly more CFU-C than adherent cells from flask cultures to which IFN- $\alpha$ was

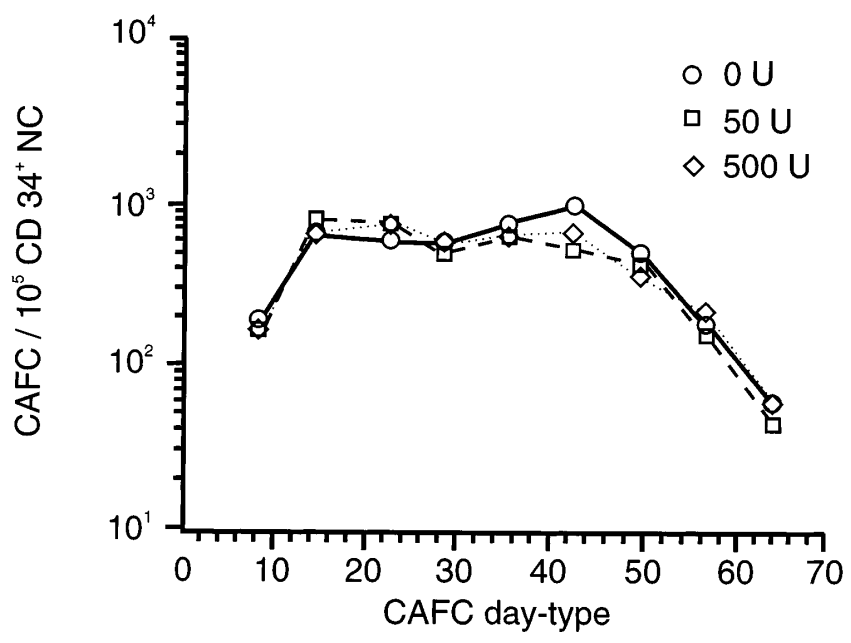

Figure 1. Weekly CAFC frequencies per $10^{5} \mathrm{CD} 34^{+} \mathrm{NC}$, obtained from the $\mathrm{BM}$ of patient 5 , cultured without IFN- $\alpha$ (open circles), or in the presence of $50 \mathrm{IU}$ (open boxes), or $500 \mathrm{IU}$ (open diamonds) IFN/ $\mathrm{ml}$ at final concentrations. added weekly to concentrations of 500 or $5,000 \mathrm{IU} / \mathrm{ml}$. No differences were apparent between responders and nonresponders.

The total number of nonadherent $\mathrm{NC}$ and CFU-C assayed during 8 wk of LTC represented all cells produced with no regard to the leukemic or normal nature of the cells. To distinctively evaluate the production of normal $\mathrm{NC}$ as compared with $\mathrm{Ph}^{+} \mathrm{NC}$, cells were analyzed by FISH with $b c r$ and $a b l$ specific probes.

Effect of IFN- $\alpha$ on production of $\mathrm{Ph}^{+} \mathrm{NCs}$. FISH analysis was performed on $\mathrm{CD}_{3} 4^{+}$progenitor cells before LTC and on NC produced after 8 wk of LTC to determine the percentages of $b c r / a b l$ positive cells. Percentages for individual patients are shown in Fig. 6, whereas median values and statistical analysis are presented in Table III. Both normal and leukemic cells were detectable before LTC in samples from responding patients as well as nonresponders. Median percentages of $\mathrm{CD} 34^{+} / \mathrm{Ph}^{+} \mathrm{NC}$ did not differ between the two groups of patients, although a wider range was observed in progenitor cells from responding patients (27-95\%). In both responders and nonresponders, the percentage of $\mathrm{Ph}^{+}$cells did not change significantly during $8 \mathrm{wk}$ of LTC in the absence of IFN- $\alpha$, con-

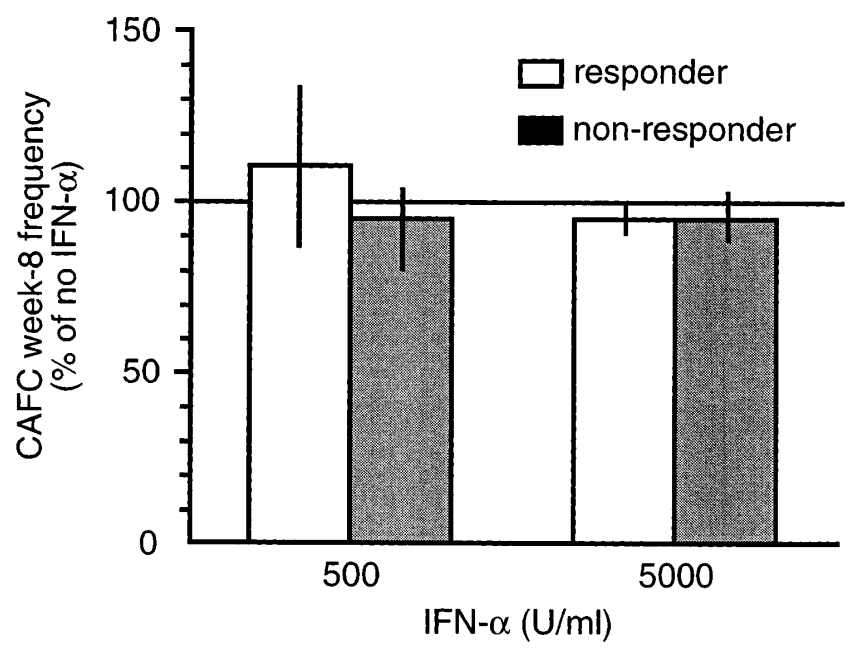

Figure 2. CAFC week 8 frequencies per $10^{5} \mathrm{CD} 34^{+} \mathrm{NC}$ expressed as mean percentages $( \pm$ SEM $)$ of parallel control cultures without IFN $-\alpha$. IFN- $\alpha$ was added weekly to final concentrations of 500 or $5,000 \mathrm{U} / \mathrm{ml}$. $\mathrm{CD} 34^{+} \mathrm{NC}$ were obtained from BM samples of clinically responding patients $(n=3)$ and patients $(n=3)$ without a cytogenetic response to IFN- $\alpha$. 


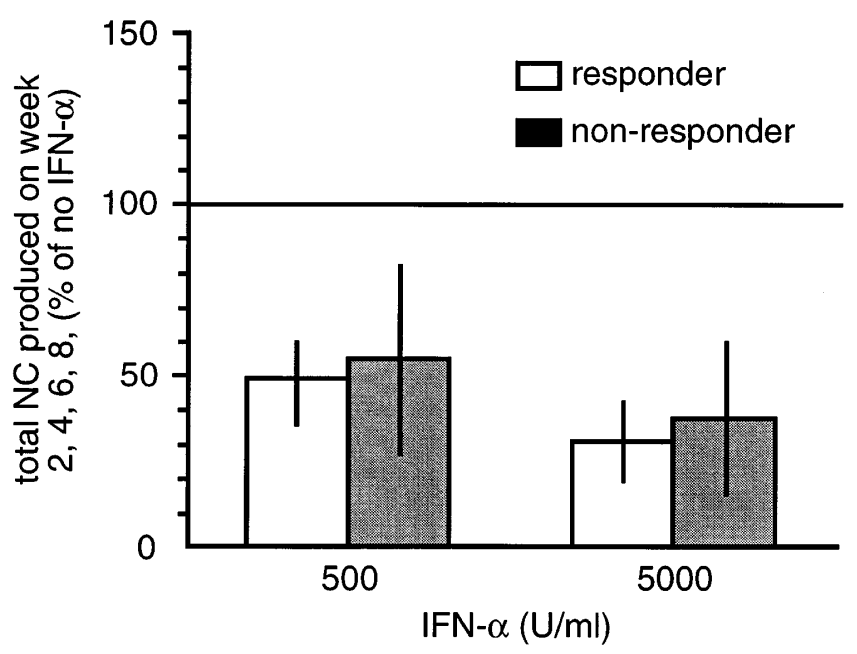

Figure 3. NCs produced at weeks $2,4,6$, and 8 in flask LTC expressed as mean percentages $( \pm$ SEM) of parallel control LTC without IFN- $\alpha$. Final concentrations of weekly added IFN- $\alpha$ were 500 and $5,000 \mathrm{U} / \mathrm{ml}$, respectively. NC production of cytogenetic responders $(n=3)$ and nonresponders $(n=3)$ were compared.

firming earlier findings that LTC on the FBMD-1 stromal cell line equally supports outgrowth of $\mathrm{Ph}^{+}$and $\mathrm{Ph}^{-}$progenitors (25). The percentage of $\mathrm{Ph}^{+} \mathrm{NC}$ produced by progenitor cells from nonresponders did not change over $8 \mathrm{wk}$ of LTC in the presence of IFN- $\alpha$. In contrast, the production of $\mathrm{Ph}^{+} \mathrm{NC}$ by progenitors from responding patients declined from 80 to $31 \%$ after $8 \mathrm{wk}$ of LTC in the presence of $5,000 \mathrm{IU} / \mathrm{ml}$ IFN- $\alpha$. The difference between responders and nonresponders was significant $\left(P=0.011\right.$, Table III). In addition, the percentage of $\mathrm{Ph}^{+}$ NC produced by responders either in the absence or presence of $5,000 \mathrm{IU} / \mathrm{ml} \mathrm{IFN}-\alpha(80$ vs. $31 \%)$ was also significant $(P=$ $0.03)$. The median percentage of $\mathrm{Ph}^{+} \mathrm{NC}$ produced in the presence of $500 \mathrm{IU} / \mathrm{ml} \mathrm{IFN}-\alpha$ also declined to 45 and $66 \%$, respectively, for responding and nonresponding patients, but this difference was of borderline significance $(P=0.077)$. Control LTC that did not include IFN- $\alpha$ showed no statistically sig-

Table III. Effect of IFN on $\mathrm{Ph}^{+}$Cell Production in LTC

\begin{tabular}{|c|c|c|c|c|c|c|}
\hline \multirow{3}{*}{$\begin{array}{l}\text { LTC } \\
\text { time point }\end{array}$} & \multirow[b]{3}{*}{ IFN dosage added } & \multicolumn{4}{|c|}{ Percentage of $\mathrm{Ph}^{+}$nucleated cells } & \multirow[b]{3}{*}{$P$ value } \\
\hline & & \multicolumn{2}{|c|}{$\begin{array}{l}\text { Responders } \\
\quad(n=6)\end{array}$} & \multicolumn{2}{|c|}{$\begin{array}{l}\text { Nonresponders } \\
\quad(n=4)\end{array}$} & \\
\hline & & Median & Range & Median & Range & \\
\hline$w k$ & $I U / m l$ & & & & & \\
\hline 0 & - & 80 & $27-95$ & 73 & $65-83$ & 0.67 \\
\hline 8 & 0 & 51 & $42-64$ & 57 & $47-84$ & 0.16 \\
\hline 8 & 500 & 45 & $37-48$ & 68 & 47-91 & 0.077 \\
\hline 8 & 5000 & 31 & $10-40$ & 66 & $52-89$ & 0.011 \\
\hline
\end{tabular}

FISH analysis was performed on $\mathrm{CD} 34^{+} \mathrm{NC}$ before $\mathrm{LTC}$ and on $\mathrm{NC}$ produced after 8 wk of LTC either in the presence or absence of IFN- $\alpha$. Median percentages of $\mathrm{Ph}^{+}$and $\mathrm{Ph}^{-} \mathrm{NC}$ are presented separately for responding and nonresponding patients and were compared using the Wilcoxon rank-sum test.

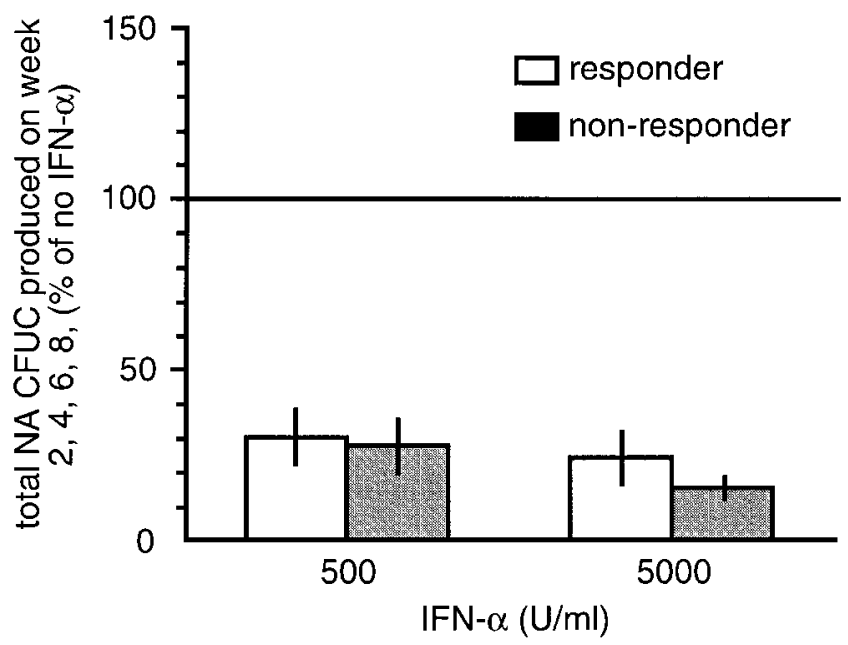

Figure 4. Nonadherent clonogenic cell production at weeks 2, 4, 6 , and 8 in flask LTC in the presence of 500 or $5,000 \mathrm{IU} / \mathrm{ml} \mathrm{IFN-} \alpha$ expressed as mean percentages $( \pm$ SEM) of parallel control LTC without IFN- $\alpha$. Responding patients $(n=3)$ and nonresponders $(n=3)$ were compared.

nificant difference $(P=0.16)$ between the percentages of $\mathrm{Ph}^{+}$ $\mathrm{NC}$ in responding $(51 \%)$ and nonresponding $(57 \%)$ patients.

\section{Discussion}

Treatment of CML patients with IFN- $\alpha$ may induce hematologic remissions in up to $75 \%$ of patients, while a cytogenetic remission may follow in $\sim 15-20 \%$ of patients $(5-9,28)$. Moreover, IFN- $\alpha$ has been shown to significantly prolong survival in CP CML. However, the survival benefit is restricted to the subgroup of patients, who develop a cytogenetic conversion as indicated by a reappearance of normal BM metaphases. A hematological response is usually achieved within 2-3 mo, but a cytogenetic response develops more slowly and it may take

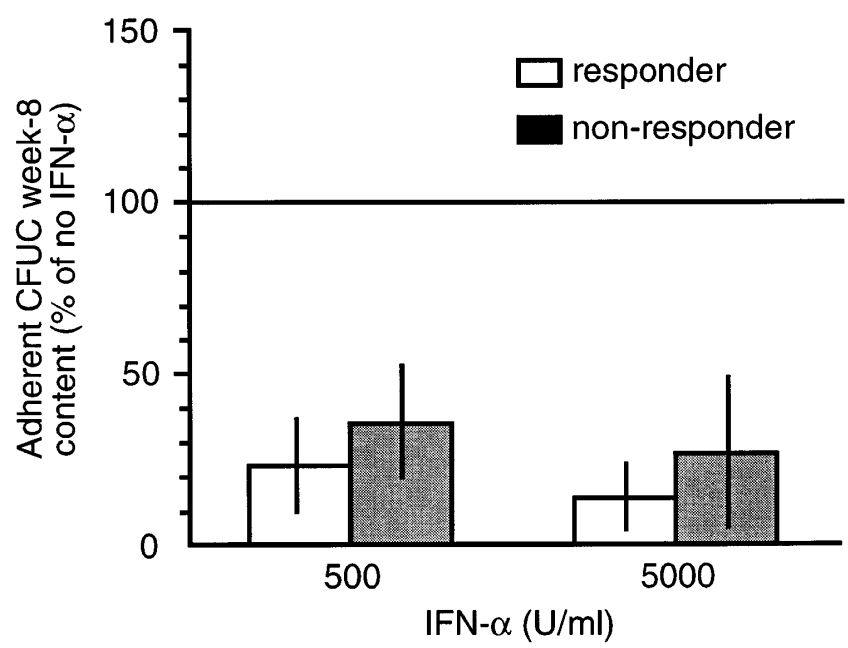

Figure 5. Clonogenic cell production by adherent cells removed after abrogation of flask LTC after $8 \mathrm{wk}$ of culture in the presence or absence of IFN- $\alpha$. Results are expressed as percentages of production by adherent cells from LTC without addition of IFN- $\alpha$. No significant differences between responders and nonresponders were observed. 


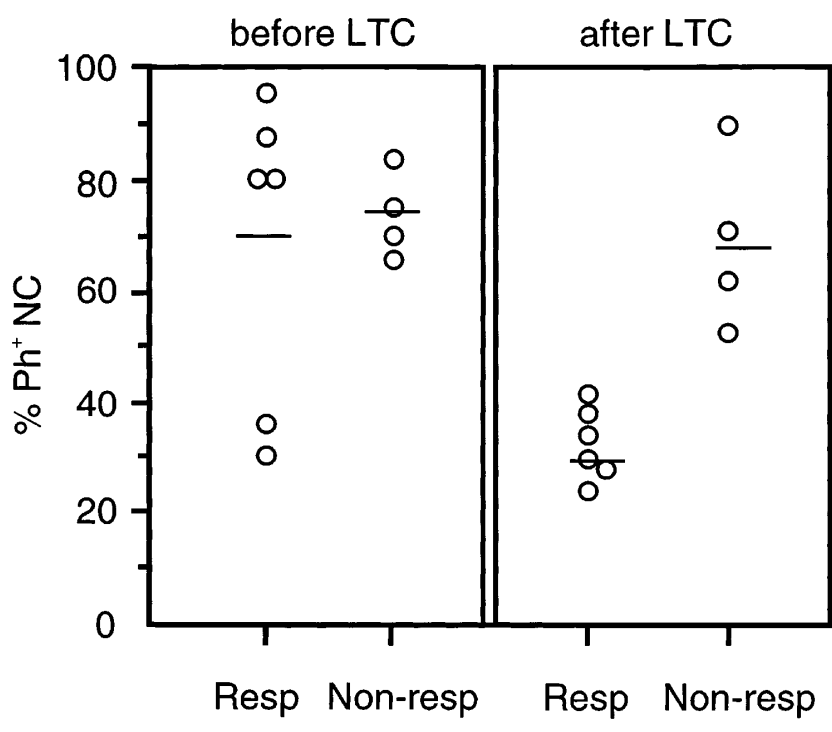

Figure 6. Percentages of $\mathrm{Ph}^{+} \mathrm{CD} 34^{+} \mathrm{NC}$ before LTC in the presence of 5,000 IU/ml IFN- $\alpha$ as compared with the percentage of $\mathrm{Ph}^{+} \mathrm{NC}$ produced after $8 \mathrm{wk}$ of LTC by CD $34^{+} \mathrm{NC}$ of patients with a clinical cytogenetic response $(n=6)$ or without a cytogenetic response $(n=4)$.

many months before patients have reached their best cytogenetic response to IFN- $\alpha$ (Tables I and II) (7-9). The underlying biological mechanism of that favorable and specific effect of IFN- $\alpha$ is still poorly understood. LTC of normal and malignant hematopoietic progenitor cells in vitro in the presence of IFN- $\alpha$ may potentially help to settle the biological basis of that therapeutic effect of IFN- $\alpha$. In this study we show that IFN- $\alpha$ does not eradicate normal or malignant CAFCs maintained in LTC, but inhibits their outgrowth. Furthermore, IFN- $\alpha$ preferentially inhibits the outgrowth of malignant progenitor cells obtained from patients with a clinical cytogenetic response. In contrast, no preferential inhibition is exerted by IFN- $\alpha$ on the outgrowth of malignant progenitor cells from clinical nonresponsive patients. These in vitro findings mimic the clinical pattern of cytogenetic conversion induced by IFN- $\alpha$ and suggest that inhibition of the outgrowth of CML progenitor cells might account for the cytogenetic response to IFN- $\alpha$.

CML is a malignancy of hematopoietic stem cells and their maintenance in LTC is a prerequisite to study antiproliferative effects of cytokines such as IFN- $\alpha$ in vitro for a prolonged period of time. It has been reported that LTCs supported by human stromal feeders of CML progenitors are hampered by a defective maintenance of malignant but not of normal progenitors $(29,30)$. Previously, we showed that both malignant and normal stem cells can be maintained for 1-2 mo efficiently in LTC, if supported by the murine cell line FBMD-1 (25). A stromal cell line of murine origin offers an additional advantage in that murine cells lack the receptor for human IFN- $\alpha$, which enabled us to study direct effects of IFN- $\alpha$ on stem cells. In addition, the relatively long time span of the LTC assay may allow for measuring effects of IFN- $\alpha$, which more closely resemble the delayed therapeutic effect in vivo. First we addressed the question of whether IFN- $\alpha$ eliminates primitive progenitor cells. No such effect was observed as indicated by unaltered frequencies of CAFC in the presence of IFN- $\alpha$. We demonstrated previously a distinct phenotype and distinct functional characteristics of early and late CAFC in sorted BM samples (21). Early CAFC are considered to represent more transiently repopulating stem cells, while week 5-8 CAFC are related to primitive stem cells with long-term ability to produce committed progenitors of different lineages. Late (weeks 5-8) CAFC are preferentially confined to the subset of CD34 Rho-123 $3^{\text {dull }}$, $\mathrm{DR}^{-}, 5 \mathrm{FU}$-resistant normal human $\mathrm{BM}$ progenitor cells. By sharing multiple functional and phenotypic characteristics with LTC initiating cells (LTC-IC), late CAFC and LTC-IC probably represent a comparable subset of progenitor cells $(23,31)$. Recently, we showed that phenotypically defined subsets of $\mathrm{CD}^{+} 4^{+}$(subfractionated on the basis of CD38- expression) CML progenitors showed distinct patterns of early and late appearing CAFC and did not differ from their normal counterparts, indicating that late appearing CAFC of CML PB or BM can be compared with week 5 LTC-IC (25). In the present study, IFN- $\alpha$ did not affect the frequency of early (weeks 2 and 3) CAFC nor late appearing (weeks 5-8) CAFC (Figs. 1 and 2), indicating that these stem cell subsets were not eliminated by IFN- $\alpha$ in that time period of LTC.

Theoretically, it is possible that malignant CAFC could be inhibited, whereas $\mathrm{Ph}^{-} \mathrm{CAFC}$ could be expanded (or vice versa). In that situation, the number of CAFC $\left(\mathrm{Ph}^{+}\right.$and $\left.\mathrm{Ph}^{-}\right)$ could remain unchanged, as observed. However, to date, we have never observed adult stem cell expansion in our CAFC system and it would be very unlikely that an inhibitory cytokine like IFN- $\alpha$ would exert such an expansion effect.

The second question, of whether IFN- $\alpha$ affects the progeny produced by CML CAFC, was studied by assaying the generation of committed progenitors in flask LTC. The production of $\mathrm{NC}$ and CFU-C by normal and malignant CAFC was dosedependently inhibited by IFN- $\alpha$ (Figs. 3 and 4). These results compare well to earlier studies by Galvani et al., who showed that IFN- $\alpha$ preferably inhibited more committed progenitors of both normal and malignant origin (32). A preferential inhibition of late progenitors may be explained by findings of Eaves et al., showing that more late than early progenitors are in cell cycle than early progenitors and may therefore be more responsive to the antiproliferative effects of IFN- $\alpha$ (33).

In this study, IFN- $\alpha$ inhibited the cell production by malignant CAFC from responding patients and nonresponding patients, but a relative stronger inhibition was observed with respect to the NC production of malignant CAFC from responders (Fig. 6 and Table III). These findings may be explained by a direct inhibitory effect of IFN- $\alpha$ or by indirect inhibition mediated by stromal cells after increased adhesion of CML progenitors to BM stroma. Several studies have shown that adhesion of CML progenitors to stromal cells is impaired. IFN- $\alpha$ may restore adhesion to BM stroma $(10-12,34)$, which may result in integrin-mediated inhibition of proliferation of CML progenitors. An effect of IFN- $\alpha$ on CML stem cells acting via increased adhesion to stromal cells is probably not involved in our study. Stroma-associated CFU-C production was not increased by IFN- $\alpha$. On the contrary, CFU-C production by adherent cells removed from flask LTC was similarly inhibited by IFN- $\alpha$ as the production of CFU-C by nonadherent cells (Fig. 5). These results as well as the unaltered week 8 $\mathrm{CAFC}$ frequencies strongly suggest that the inhibition of nonadherent CFU-C generation by IFN- $\alpha$ did not result from enhanced progenitor adhesion. An indirect effect of IFN- $\alpha$ via stroma cells is also less likely because the stromal cells do not express receptors for human IFN- $\alpha$. Nevertheless, inhibitory 
effects mediated by stromal cells could be involved. It is possible, as indicated by findings by Bhatia et al. (12), that IFN- $\alpha$ restores normal signaling through $\beta 1$-integrins by restoring a defective signaling pathway within the malignant cell. Clinically, clear-cut differences between cytogenetically responding patients and nonresponders with respect to restoration of integrin signaling by IFN- $\alpha$ have not been reported yet. Therefore, it remains to be demonstrated whether $\beta 1$-integrin-mediated inhibition accounts for the cytogenetic response observed clinically.

Alternatively, our results are more readily explained by a direct inhibitory effect via the IFN- $\alpha$ signaling pathway, which may result in cell cycle exit. Several hematopoietic cell lines respond to IFN- $\alpha$ by a cell cycle arrest at the G0/G1 phase, characterized by the accumulation of nondividing cells with $2 \mathrm{n}$ DNA content (35-39). Specific interactions between IFN- $\alpha$ receptor-generated signaling and the cell cycle phase have been identified. It has been shown that IFN- $\alpha$ may impose a number of proliferative restrictions via cell cycle controlling genes such as inhibition of cyclin-dependent kinases (40), downregulation of c-myc, and reduction of DNA binding activity of E2F (41). On the other hand, enhanced tyrosine kinase activity of p210 ${ }^{B C R / A B L}$ may enhance the activity of E2F and thereby initiate transcription of c-myc (42). However, the opposing effects of IFN- $\alpha$ and $\mathrm{p} 210^{B C R / A B L}$ on the cell cycle remain largely to be investigated. Such studies may give a clue as to how IFN- $\alpha$ exerts an antiproliferative effect without elimination of CAFC, as demonstrated in this study. Our in vitro findings compare well to previous clinical findings by Talpaz et al. (43) and by Hochhaus et al. (44). Both clinical studies demonstrated that the persistence of leukemic progenitors during IFN- $\alpha$ induced cytogenetic remission. It was suggested that IFN- $\alpha$ interferes with the maturation and expansion of leukemic progenitors. Our results would suggest that IFN $-\alpha$ may predominantly affect hematopoietic progenitor cells at a stage of development beyond the initiation of CAs.

In conclusion, this work presents the first in vitro model mimicking the cytogenetic conversion induced by IFN- $\alpha$ in CML. It suggests that cytogenetic responses are predominantly induced by a preferential functional inhibition of the outgrowth of CML stem cells.

\section{Acknowledgments}

We thank Bep Smit and Adrie Boudewijn for excellent technical assistance, Kitty Oosterman for excellent secretarial assistance, and Ron van der Holt for excellent statistical analysis.

\section{References}

1. Fialkow, P.J., R.J. Jacobson, and T. Papayannopoulou. 1977. Chronic myeloid leukemia: clonal origin in a stem cell common to the granulocyte, erythrocyte, platelet and monocyte/macrophage. Am. J. Med. 63:125-130.

2. Groffen, J., J.R. Stephenson, N. Heisterkamp, A. de Klein, C.R. Bartram, and G. Grosveld. 1984. Philadelphia chromosomal breakpoints are clustered within a limited area, bcr, on chromosome 22. Cell. 36:93-99.

3. Melo, J.V. 1996. The molecular biology of chronic myeloid leukemia. Leukemia. 10:751-756.

4. McGlave, P.B. 1992. Therapy of chronic myelogenous leukemia with related or unrelated donor bone marrow. Leukemia. 6:115-117.

5. Talpaz, M., K. McCredie, G.M. Mavligit, and J.U. Gutterman. 1983. Leucocyte interferon-reduced myeloid cytoreduction in chronic myelogenous leukemia. Blood. 62:689-692.

6. Talpaz, M., H.N. Kantarjian, K.B. McCredie, J.M. Trujillo, M.J. Keating, and J.U. Gutterman. 1986. Hematologic remission and cytogenetic improve- ment induced by recombinant human interferon- $\alpha$ in chronic myelogenous leukemia. N. Engl. J. Med. 314:1065-1069.

7. Kantarjian, H.M., T.L. Smith, S. O'Brien, M. Beran, S. Pierce, and M. Talpaz. 1995. Prolonged survival in chronic myelogenous leukemia after cytogenetic response to interferon- $\alpha$ therapy. Ann. Intern. Med. 122:254-261.

8. The Italian Cooperative Study Group on Chronic Myeloid Leukemia 1994. Interferon-alpha-2a as compared with conventional chemotherapy for the treatment of chronic myeloid leukemia. N. Engl. J. Med. 330:820-825.

9. Allan, N.C., S.M. Richards, P.C.A. Shepherd, on behalf of the UK Medical Research Council's Working Parties for Therapeutic Trials in Adult Leukaemia. 1995. UK Medical Research Council randomised, multicenter trial of interferon- $\alpha 1$ for chronic myeloid leukemia: improved survival irrespective of cytogenetic response. Lancet. 345:1392-1397.

10. Dowding, Ch., G. Ai-Pu, J. Osterholz, M. Siczkowiski, J. Goldman, and M. Gordon. 1991. Interferon- $\alpha$ overrides the deficient adhesion of chronic myeloid leukemia primitive progenitor cells to bone marrow stromal cells. Blood. 78:499-505.

11. Bhatia, R., E.R. Wayner, P.B. McGlave, and C.M. Verfaillie. 1994. Interferon- $\alpha$ restores normal adhesion of chronic myelogenous leukemia hematopoietic progenitors to bone marrow stroma by correcting impaired $\beta 1$ integrin receptor function. J. Clin. Invest. 94:384-391.

12. Bhatia, R., J.B. McCarthy, and C.M. Verfaillie. 1996. Interferon- $\alpha$ restores normal $\beta 1$ integrin-mediated inhibition of hematopoietic progenitor proliferation by the marrow microenvironment in chronic myelogenous leukemia. Blood. 9:3883-3891.

13. Santucci, M.A., G. Visani, D. Russo, A. Zaccaria, N. Testoni, P. Tosi, E. Zuffa, R. Fanin, and S. Tura. 1992. In vitro activity of alpha-interferon on granulocyte macrophage precursors in chronic myeloid leukemia (CML): correlation with clinical responsiveness. Leuk. Lymphoma. 6:155-160.

14. Carmelo, C.S., M. Cazzola, A. Ganser, G. Bergamaschi, P. Pedrazzoli, D. Hoelzer, and E. Ascari. 1988. Synergistic antiproliferative effect of recombinant interferon- $\gamma$ with recombinant interferon- $\alpha$ on chronic myelogenous leukemia hematopoietic progenitor cells (CFU-GEMM, CFU-Mk, BFU-e and CFU-GM). Blood. 72:1293-1299.

15. Estrov, Z., R. Kurzrock, and M. Wetzler. 1991. Suppression of chronic myelogenous leukemia colony growth by interleukin-1 (IL-1) receptor antagonist and soluble IL-1 receptors: a novel application for inhibitors of IL-1 activity. Blood. 78:1476-1484.

16. Selleri, C., T. Sato, L. Del Vecchio, L. Luciano, A.J. Barrett, B. Rotoli, N.S. Young, and J.P. Maciejewski. 1997. Involvement of Fas-mediated apoptosis in the inhibitory effects of interferon- $\alpha$ in chronic myelogenous leukemia. Blood. 89:957-964.

17. Ploemacher, R.E., J.P. van der Sluijs, J.S.A. Voerman, and N.H.C. Brons. 1989. An in vitro limiting-dilution assay of long-term repopulating hematopoietic stem cells in the mouse. Blood. 74:2755-2763.

18. Ploemacher, R.E. J.P van der Sluijs, C.A.J. van Beurden, M.R.M. Baert, and P.L. Chan. 1991. Use of limiting dilution type long-term marrow cultures in frequency analysis of marrow-repopulating and spleen colony-forming hematopoietic stem cells in the mouse. Blood. 78:2527-2533.

19. Ploemacher, R.E., J.C.M. van der Loo, C.A.J. van Beurden, and M.R.M. Baert. 1993. Wheat germ agglutinin affinity of murine hemopoietic stem cell subpopulation is an inverse function of their long-term repopulating ability in vitro and in vivo. Leukemia. 7:120-130.

20. Breems, D.A., A. Baelde, J.J.B. Boesen, E.A.W. Blokland, K.B. Brouwer, S. Fruehauf, D. Valerio, and R.E. Ploemacher. 1995. Rhesus monkey cobblestone area forming cell assay allows assessment of pre- and post-transplant gene transfer efficiency in a series of hematopoietic stem cell subsets. Exp. Hematol. 23:844a. (Abstr.)

21. Breems, D.A., E.A.W. Blokland, S. Neben, and R.E. Ploemacher. 1994 Frequency analysis of human primitive haematopoietic stem cell subsets using a cobblestone area forming cell assay. Leukemia. 8:1095-1104.

22. Ploemacher, R.E. 1994. Cobblestone area forming cell (CAFC) assay. In CRC Culture of Specialized Cells. Culture of Hematopoietic Cells. R.I. Freshney, I.B. Pragnell, and M.G. Freshney, editors. Wiley-Liss Inc., New York. 1-21.

23. van der Loo, J.C.M., C. van den Bos, M.R.M. Baert, G. Wagemaker, and R.E. Ploemacher. 1994. Stable multilineage hemopoietic chimerism in alpha-talassemic mice induced by a bone marrow subpopulation that excludes the majority of day-12 colony-forming units. Blood. 83:1769-1777.

24. Terpstra, W., R.E. Ploemacher, A. Prins, K. van Lom, K. Pouwels, A.W. Wognum, B. Löwenberg, and J.J. Wielenga. 1996. Fluorouracil spares AML cells with long-term abilities in immunodeficient mice and in stromal culture. Blood. 88:1944-1949.

25. Cornelissen, J.J., A.W. Wognum, R.E. Ploemacher, F. Frassoni, G. Wagemaker, A. Hagemeijer, and B. Löwenberg. 1997. Efficient long-term maintenance of chronic myeloid leukemic cobblestone area forming cells on a murine stromal cell line. Leukemia. 11:126-133.

26. Berenson, R.J., R.G. Andrews, W.I. Bensinger, D. Kalamasz, G. Knitter, C.D. Buckner, and I.D. Bernstein. 1988. Antigen CD $34^{+}$marrow cells engraft lethally irradiated baboons. J. Clin. Invest. 81:951-955.

27. Arnoldus, E.P.J., J. Wiegant, I.A. Noordermeer, J.W. Wessels, G.C. Bevestock, G.C. Grosveld, M. van der Ploeg, and A.K. Raap. 1990. Detection 
of the Philadelphia chromosome in interphase nuclei. Cytogenet. Cell. Genet. 54:108-111.

28. Hehlmann, R. 1996. Chronic myelogenous leukemia: does interferonalpha prolong life? Leukemia. 10:193-196.

29. Udomsakdi, C., C.J. Eaves, B. Swolin, E.S. Reid, M.J. Barnett, and A.C. Eaves. 1992. Rapid decline of chronic myeloid leukemic cells in long-term culture due to a defect at the leukemic stem cell level. Proc. Natl. Acad. Sci. USA. 89:6192-6196.

30. Agarwal, R., S. Doren, B. Hicks, and C.E. Dunbar. 1995. Long-term culture of chronic myelogenous leukemia marrow cells on stem cell factor-deficient stroma favors benign progenitors. Blood. 85:1306-1312.

31. Sutherland, H.J., P.M. Lansdorp, D.H. Henkelman, A.C. Eaves, and C.J. Eaves. 1990. Functional characterization of individual human hematopoietic stem cells cultured at limiting dilution on supportive marrow stromal layers. Proc. Natl. Acad. Sci. USA. 87:3584-3588.

32. Galvani, D.W., and J.C. Cawley. 1989. Mechanism of action of $\alpha$ interferon in chronic granulocytic leukaemia: evidence for preferential inhibition of late progenitors. Br. J. Haematol. 73:475-479.

33. Eaves, A.C., J.D. Cashman, L.A. Gaboury, D.G. Kalousek, and C.J. Eaves. 1986. Unregulated proliferation of primitive CML progenitors in the presence of normal adherent cells. Proc. Natl. Acad. Sci. USA. 83:5306-5310.

34. Upadhyaya, G., S.C. Guba, S.A. Sih, A.P. Feinberg, M. Talpaz, H.M. Kantarjian, A.B. Deisseroth, and S.G. Emerson. 1991. Interferon-alpha restores the deficient expression of the cytoadhesion molecule lymphocyte function antigen-3 by chronic myelogenous leukemia progenitor cells. J. Clin. Invest. 88:2131-2136.

35. Einat, M., D. Resnitzky, and A. Kimchi. 1985. Close links between reduction of c-myc expression by interferon and G0/G1 arrest. Nature. 313:597600

36. Kimchi, A., D. Resnitzky, R. Ber, and G. Gat. 1988. Recessive genetic deregulation abrogates c-myc suppression by interferon and is implicated in oncogenesis. Mol. Cell. Biol. 8:2828-2836.

37. Burke, L.B., A. Bybee, and N.S.B. Thomas. 1992. The retinoblastoma protein is partially phosphorylated during early G1 in cycling cells but not G1 cells arrested with interferon- $\alpha$. Oncogene. 7:783-788.

38. Kimchi, A. 1992. Cytokine triggered molecular pathways that control cell cycle arrest. J. Cell. Biochem. 50:1-9.

39. Melamed, D., N. Tiefenbrun, A. Yarden, and A. Kimchi. 1993. Interferons and interleukin-6 suppress the DNA binding activity of E2F in growth sensitive hematopoietic cells. Mol. Cell. Biol. 13:5255-5265.

40. Tiefenbrun, N., D. Melamed, N. Levy, D. Resnitzky, I. Hofmann, S.I. Reed, and A. Kimchi. 1996. Alpha interferon suppresses the cyclin D3 and $c d c 25 A$ genes, leading to a reversible $\mathrm{G}_{0}$-like arrest. Mol. Cell. Biol. 16:39343944.

41. Resnitzky, D., N. Tiefenbrun, H. Berissi, and A. Kimchi. 1992. Interferons and interleukin-6 suppress phosphorylation of the retinoblastoma protein in growth-sensitive hematopoietic cells. Proc. Natl. Acad. Sci. USA. 89:402-406.

42. Stewart, M.J., S. Litz-Jackson, G.S. Burgess, E.A. Williamson, D.S. Leibowitz, and H.S. Boswell. 1995. Role for E2F1 in p210 BCR-ABL downstream regulation of c-myc transcription initiation. Studies in murine myeloid cells Leukemia. 9:1-9.

43. Talpaz, M., Z. Estrov, H. Kantarjian, S. Ku, A. Foteh, and R. Kurzroch. 1994. Persistence of dormant leukemic progenitors during interferon-induced remission in chronic myelogenous leukemia. J. Clin. Invest. 94:1383-1389.

44. Hochhaus, A., F. Lin, A. Reiter, H. Skladny, P.J. Mason, F. van Rhee, P.C. Shepherd, N.C. Allan, R. Hehlmann, J.M. Goldman, and N.C. Cross. 1996. Quantification of residual disease in chronic myelogenous leukemia patients on interferon-alpha therapy by competitive polymerase chain reaction. Blood. 87 : 1549-1555. 